\title{
Influence of radiation and drought on gas exchange of Austrocedrus chilensis seedlings
}

\author{
Influencia de la radiación y la sequía en el intercambio gaseoso de plantines \\ de Austrocedrus chilensis
}

\author{
Javier Enrique Gyenge, b*, María Elena Fernández ${ }^{a}$, b, Tomás Schlichter ${ }^{a}$ \\ *Corresponding Author: aINTA Estación Experimental Agropecuaria Bariloche, CC 277 (8400), San Carlos de Bariloche, \\ Argentina, phone: 54-2944-422731, fax: 54-2944-424991, jgyenge@ bariloche.inta.gov.ar

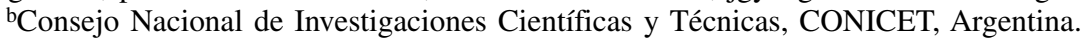

\begin{abstract}
SUMMARY
Austrocedrus chilensis is a conifer from Patagonia adapted to a wide moisture gradient. In xeric environments, its natural or artificial recruitment only occurs under nurse shrubs during normal rainfall years. In spite of its importance in ecological and economical terms, little information is available about the physiology of this species. Previous field measurements in experimental plantation revealed that seedlings without plant cover had lower survival, photosynthetic rates and predawn water potential than those planted under trees. So, the response of stomata to radiation and vapor pressure deficit, and the effect of drought stress on photosynthesis and transpiration of $A$. chilensis seedlings were studied under controlled conditions. Even when soil water was not limiting, all seedlings showed an early stomatal closure in response to moderate evaporative demand. Photosynthetic parameters and instantaneous water use efficiency suggested that microenvironments with intermediate shade are the best for A. chilensis $\mathrm{CO}_{2}$ uptake. We suggest that the early stomatal closure could result in damage in leaves or the base of the stem by oveheating, explaining low survival when grown without shade. As a whole, our results may contribute to understanding the need for nurse plants in the establishment of the species.
\end{abstract}

Key words: photosynthesis, stomatal conductance, transpiration, instantaneous water use efficiency.

\section{RESUMEN}

Austrocedrus chilensis es una conífera endémica de la Patagonia adaptada a un amplio gradiente de condiciones de humedad. El reclutamiento en lugares xéricos sólo se produce bajo arbustos nodrizas en años de precipitación regular. A pesar de su importancia ecológica y económica, existe escasa información sobre la fisiología de esta especie. Plantaciones experimentales con esta especie revelaron que las plantas sin cobertura vegetal mostraron menores supervivencias, tasas fotosintéticas y potencial agua que los plantines bajo cobertura. En este trabajo se midió bajo condiciones controladas la respuesta estomática a la radiación y al déficit de presión de vapor, y el efecto de la sequía sobre la fotosíntesis y transpiración de plantines de A. chilensis. Los plantines cerraron sus estomas en respuesta a una demanda evaporativa moderada aun cuando el agua en el suelo no fue limitante. Los parámetros fotosintéticos demostraron que los ambientes semisombreados son los óptimos para plantines de A. chilensis. Se sugiere que el cierre estomático temprano podría implicar daños en las hojas o en la base del tallo por sobrecalentamiento. En conjunto, los datos contribuirían al entendimiento de la necesidad de una planta nodriza en el establecimiento de esta especie.

Palabras clave: fotosíntesis, conductancia estomática, transpiración, eficiencia instantánea en el uso del agua.

\section{INTRODUCTION}

Austrocedrus chilensis (D. Don) Pic. Ser. et Bizzarri is a native conifer from Northern Patagonia, Argentina $\left(38^{\circ}\right.$ to $42^{\circ} \mathrm{S}$ ). Considered one of the most drought tolerant tree species of the region, it ranges along a wide geographic area, from sites with $300 \mathrm{~mm}$ of mean annual precipitation to sites exceeding 2,500 mm (Dezzotti and Sancholuz 1991). Northern Patagonia has a typical Mediterranean climate, with fall-winter precipitation and summer droughts. Freezing temperatures limit growth in early spring and low soil moisture and high vapor pressure deficit (VPD) limit growth in late summer (Dezzotti and Sancholuz 1991). Generally this type of climate imposes hydrologic and temperature limitations to ecosystem gas exchange. Several studies have pointed out that at xeric sites $(<1,000 \mathrm{~mm}$ $\mathrm{yr}^{-1}$ of precipitation), natural regeneration of A. chilensis is highly restricted, both temporally and spatially. Mostly, 
seedlings of $A$. chilensis are restricted to the presence of shrubs, under which soil water in microsites is higher than in the open (Kitzberger 1995). However, it seems that excess radiation was a more limiting factor than soil water content for seedling survival of this species (Kitzberger et al. 2000, Letourneau et al. 2004). Precipitation and average temperature during summer explain recruitment patterns of A. chilensis (Gobbi and Schlichter 1998, Kitzberger et al. 2000). Soil temperature, at 1 and $5 \mathrm{~cm}$ of soil depth, were 100 and $70 \%$ higher in sunny places than under shrubs (Letournaeu et al. 2004). Those authors found an increase in the facilitative strength of shrubs when the atmospheric demand was more severe. Seedlings showed larger shootroot ratio (S/R) and leaf area- sapwood area ratio (L/SA) in shaded than in un-shaded places (Letournaeu et al. 2004). These changes in allometric parameters increase the capacity to drive water to leaves, changing specific leaf area conductivity (Maherali et al. 1997). However, another important limiting factor in this pathway is the stomatal conductance (gs) which could be important in terms of survival. Kolb and Robberecht (1996) found a correlation between pine seedlings survival and gs. They suggested that a high transpiration indirectly cooled seedlings stems by means of increased rate of water flow through the stem xylem. Therefore seedlings in which transpiration was restricted by stomatal closure (because of low soil water availability and/or high VPD) would have a limited capacity for stem cooling and so would be more susceptible to heat stress. In addition, high radiation and temperature could damage photosynthetic apparatus when stomata are closed (Epron 1997). Gyenge et al. (2005) found that seedlings of A. chilensis had high total plant resistance, with more than $70 \%$ of their water hydraulic resistance placed at leaf level. These could imply a low capacity to transport water from the soil to the leaf. Also, seedlings of Quercus spp. subjected to soil and stem base heat showed rapid declines in rates of transpiration, photosyntesis and survival; demonstrating that heating caused shoot death even without exposition of the upper stem or foliage to heat (Huddle and Pallardy 1996). Based on the hydraulic resistance of seedlings, we hipothesized that A. chilensis close their stomata in response to VPD even when soil water content is relatively high. This might be the reason of the decrease in seedling survival in sunny places due to overheating or photo-destruction.

There exists considerable ecological information about A. chilensis (Dezzotti and Sancholuz 1991, Gobbi and Schlichter 1998, Kitzberger et al. 2000). However, little is known about physiological characteristics of this species that could help to understand its ecological patterns, particularly in relation to effects of soil water shortage and climatic conditions on leaf gas exchange. The present study is part of a larger study dealing with the feasibility of using A. chilensis in commercial forest plantations. A previous study established an experimental plantation of A. chilensis under shelter provided by a young (15 years old) ponderosa pine (Pinus ponderosa L.) plantation and in an open grassland area (Schlichter 2004). In the later situation, survival of seedlings was less than $40 \%$, while survival of seedlings growing under pines was over $90 \%$. In addition, field-measured photosynthesis and predawn water potential were lower in seedlings growing in the open compared to seedlings growing under pines (Schlichter 2004). Following those results, the objective of this study was to characterize, under more controlled conditions, the effect of drought and climatic conditions (mainly VPD and radiation level) on leaf gas exchange of A. chilensis seedlings. In particular, we studied (a) the relationship between stomatal conductance (gs) and climatic conditions (radiation and VPD) as well as with plant water status; (b) the limitation in carbon acquisition imposed by stomata; (c) the instantaneous water use efficiency and (d) the response of net photosynthesis to radiation level. All these variables were measured in seedlings grown under controlled environmental conditions in a glasshouse.

\section{METHODS}

Three-years old seedlings of A. chilensis were grown in the tree nursery of the Forest Genetic Group of EEA Bariloche INTA (National Institute of Agricultural Technology, Argentina) with the same procedure as the one used for seedlings planted in the field (Schlichter 2004). Seeds were collected from trees (cones of 399 trees from 16 populations, Pastorino 2000) growing around Bariloche city. One year old seedlings were grown in $0.71(6 \times 25 \mathrm{~cm})$ pots in a soil similar to that of the site where seeds were collected (sandy to loam-sandy texture). Neither fertilization nor artificial light was supplied. At the beginning of the experiment, seedlings were in average $3.3 \mathrm{~mm}$ in diameter at the root collar and less than $15 \mathrm{~cm}$ in height. Plants used in both experiments were randomly selected from more than 1,000 seedlings of the tree nursery.

Experiment 1: response of stomata to climatic conditions. Air temperature, air relative humidity, photosynthetic photon flux density (PPFD, $\mu \mathrm{mol} \mathrm{m} \mathrm{m}^{-2} \mathrm{~s}^{-1}$ ), stomatal conductance $\left(\mathrm{gs}, \mathrm{mol} \mathrm{m} \mathrm{m}^{-2} \mathrm{~s}^{-1}\right)$, transpiration $\left(\mathrm{E}, \mathrm{mol} \mathrm{m} \mathrm{m}^{-2} \mathrm{~s}^{-1}\right)$ and net photosynthesis (A, $\mu \mathrm{mol} \mathrm{m} \mathrm{m}^{-2} \mathrm{~s}^{-1}$ ) of well watered and water stressed seedlings were simultaneously measured. Measurements were carried out for three days during the growing season, with a LICOR 6200 (Li-Cor, Lincoln, Nebraska, USA). The experimental treatments consisted of different levels of water stress. Forty seedlings were randomly distributed in the mentioned two treatments: well watered (20 seedlings) and water-stressed plants (20 seedlings). In the well watered treatment, seedlings were irrigated to field capacity every two days. Seedlings in the drought-stressed treatment were watered to field capacity only one time at the beginning of the experiment. In each day of measurement, drought-stressed seedlings 
were randomly selected from the initial pool of seedlings. At each sampling point, measurements were taken every one or two hours starting in pre-dawn and finishing in the evening. Different plants were used each day. Only 12 plants could be measured during each day of sampling to have minimum variation in climatic conditions. Eight plants were measured during the first day of measurement (Feb 29) (well watered, original physiological state of seedlings); 12 plants were measured in March 2 (six well watered and six water stressed plants); and 10 plants in March 13 (six well watered plants and four water stressed plants). Due to the small size of plants and their limited number of branches, water status of all plants measured with the LICOR 6200 equipment was monitored with a pressure chamber (PMS Instrument, Corvallis, Oregon, USA) in pre-dawn ( $\psi$ pd) the day after the measurements. To assess the area and the specific leaf area (SLA, $\mathrm{m}^{2}$ $\mathrm{kg}^{-1}$ ), branches sampled with the LICOR 6200 were cut after measurements, measured using a digital scanner, oven dried $\left(70^{\circ} \mathrm{C}\right)$ and weighed.

Photosynthesis at PPFD $>500 \mu \mathrm{mol} \mathrm{m}^{-2} \mathrm{~s}^{-1}$ (at light saturation) and leaf transpiration of well watered and water stressed plants were related with gs measured on March 2 and 13. Instantaneous water use efficiency was calculated as the ratio between carbon gain in photosynthesis and water loss in transpiration $(\mathrm{A} / \mathrm{E})$. Vapor pressure deficit (VPD, $\mathrm{kPa}$ ) was assessed from temperature and relative humidity of the air assuming that leaves had the same temperature as the air (Ewers and Oren 2000). The adjusted models that described the relationships between variables in each day were compared using $F$ tests with an $\alpha=0.05$ (Neter and Wasserman 1974).

Experiment 2: relationship between net photosynthesis and PPFD. In order to determine photosynthetic performance of $A$. chilensis seedlings under non limiting water availability, curves relating net photosynthesis and PPFD of eight well watered plants were drawn. Instantaneous radiation levels were obtained with shade cloth of different densities, from 2,000 to $0 \mu \mathrm{mol} \mathrm{m}{ }^{-2} \mathrm{~s}^{-1}$ similarly to what was done by Fernández et al. (2006). Carbon dioxide exchange, PPFD, gs, relative humidity and temperature, were measured with a LICOR 6200 (Li-Cor, Lincoln, Nebraska, USA). After that, sampled branches were cut, oven-dried and weighed.

The model fitted to the data was a rectangular hyperbola commonly used to describe the response of photosynthesis to radiation (Landsberg 1977):

$\mathrm{A}=\mathrm{A}_{\max } \mathrm{QY}(\mathrm{PPFD}-\mathrm{CP}) /\left[\mathrm{A}_{\max }+\mathrm{QY}(\mathrm{PPFD}-\mathrm{CP})\right]$

where $\mathrm{A}=\mathrm{CO}_{2}$ assimilation (net photosynthetic rate); $\mathrm{A}_{\max }=$ maximum assimilation rate; $\mathrm{QY}=$ apparent quantum yield (slope of the first part of the curve); $\mathrm{CP}=$ light compensation point, and $\mathrm{PPFD}=$ photosynthetic photon flux density (independent variable).

\section{RESULTS}

Response of stomata to climatic conditions. Stomatal conductance increased linearly with PPFD only at values of PPFD $<50 \mu \mathrm{mol} \mathrm{m}^{-2} \mathrm{~s}^{-1}$ (figure 1), after which it remained nearly constant.

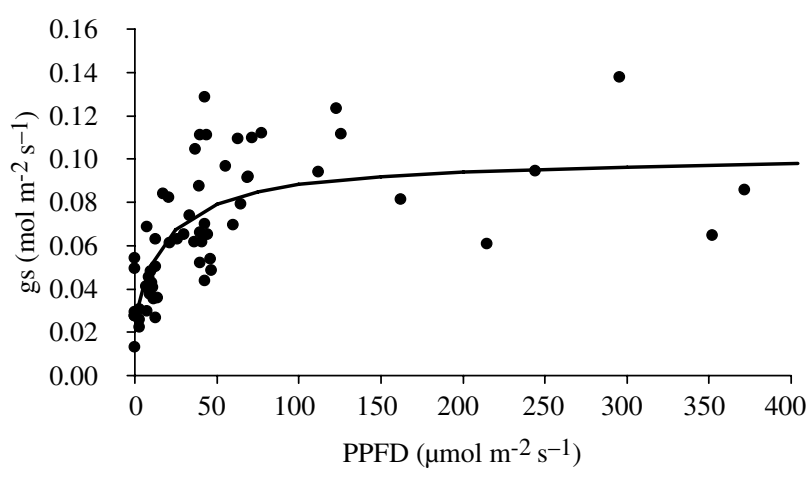

Figure 1. Response of stomatal conductance $\left(\mathrm{gs}, \mathrm{mol} \mathrm{m}^{-2} \mathrm{~s}^{-1}\right)$ to photosynthetic photon flux density (PPFD, $\mu \mathrm{mol} \mathrm{m}{ }^{-2} \mathrm{~s}^{-1}$ ) measured in seedlings of Austrocedrus chilensis. Each point represents one measurement.

Respuesta de la conductancia estomática ( $\mathrm{gs}, \mathrm{mol} \mathrm{m}^{-2} \mathrm{~s}^{-1}$ ) a la densidad de flujo de fotones fotosintéticos (PPFD, $\mu \mathrm{mol} \mathrm{m}{ }^{-2} \mathrm{~s}^{-1}$ ) medido en plantines de Austrocedrus chilensis. Cada punto representa una medición.

Maximum stomatal conductance (at saturation PPFD) of all plants was exponentially related with $\psi$ pd (figure 2). This pattern was observed during the day in which VPD was always lower than $2 \mathrm{kPa}$. Stomata reduced their conductance abruptly when $\psi$ pd was lower than $-0.5 \mathrm{MPa}$. After that value, the rate of gs reduction was lower and nearly constant, reaching a minimum gs of about $0.04 \mathrm{~mol}$ $\mathrm{m}^{-2} \mathrm{~s}^{-1}$. A similar pattern was found in $\mathrm{A} / \mathrm{E}$ in relation to upd (data not shown), indicating a great decrease in $\mathrm{A} / \mathrm{E}$ when $\psi$ pd was lower than $-1 \mathrm{MPa}$.

Daily patterns of gs versus VPD measured in well watered and water stressed plants during three days (February 29, and March 2 and 13) are shown in figure 3. To avoid the influence of light level on gs, only gs values when PPFD $>500 \mu \mathrm{mol} \mathrm{m}{ }^{-2} \mathrm{~s}^{-1}$ were plotted. No differences in radiation were measured among the three days, reaching maximum values of $1650 \mu \mathrm{mol} \mathrm{m} \mathrm{m}^{-2} \mathrm{~s}^{-1}$. Morning values of gs measured in well watered plants (maximum values) were around $0.11 \mathrm{~mol} \mathrm{~m}^{-2} \mathrm{~s}^{-1}$. Stomatal conductance was relatively stable during February 29 and March 2 (figure 3 ) in correspondence to nearly constant values of VPD, which never exceeded $2.5 \mathrm{kPa}$. During the third day (March 13, figure 3), VPD reached higher values with a maximum of $3.5 \mathrm{kPa}$ at midday, while gs decreased in relation to the increment of VPD. The lower values of 
gs were about $0.05 \mathrm{~mol} \mathrm{~m}^{-2} \mathrm{~s}^{-1}$ in the afternoon. On the other hand, gs of water stressed plants responded to VPD with a pattern similar to that for well watered plants, but the magnitude of the response depended on $\psi$ pd. Severely stressed plants ( $\psi \mathrm{pd}<-2.0 \mathrm{MPa})$ had their stomata almost closed during the whole day, and for this reason did not respond to VPD.

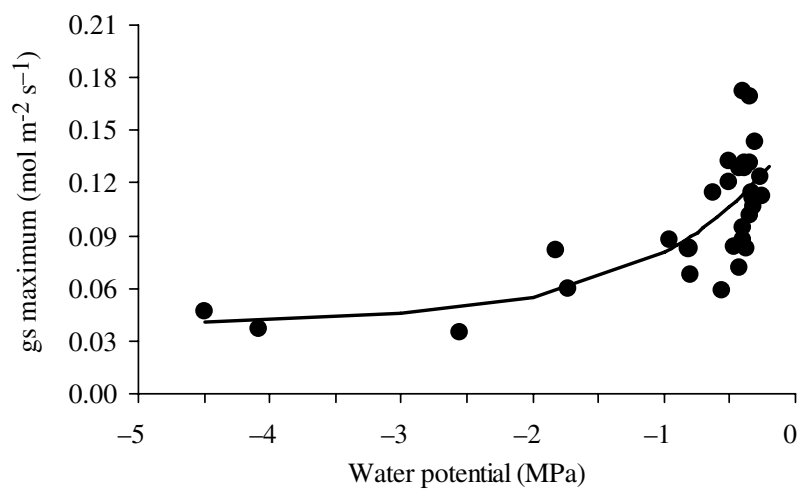

Figure 2. Maximum stomatal conductance ( $\mathrm{gs} \max , \mathrm{mol} \mathrm{m}^{-2} \mathrm{~s}^{-1}$, PPFD $>500 \mu \mathrm{mol} \mathrm{m} \mathrm{m}^{-2} \mathrm{~s}^{-1}$ ) related with predawn water potential (-MPa) measured in seedlings of Austrocedrus chilensis. Each point represents one seedling.

Máxima conductancia estomática ( $g s \max , \operatorname{mol~m} \mathrm{m}^{-2} \mathrm{~s}^{-1}$, PPFD $>500 \mu \mathrm{mol} \mathrm{m} \mathrm{m}^{-2} \mathrm{~s}^{-1}$ ) relacionada con el potencial agua en prealba (-MPa) medida en plantines de Austrocedrus chilensis. Cada punto representa un individuo.
The reduction in gs due to water stress implied a decrease in carbon exchange. A linear relationship was observed between photosynthesis at PPFD > $500 \mu \mathrm{mol}$ $\mathrm{m}^{-2} \mathrm{~s}^{-1}$ and gs in well watered and water stressed plants (figure 4). There was a positive net $\mathrm{CO}_{2}$ assimilation even when stomata were almost closed (approximately 0.03 $\mathrm{mol} \mathrm{m} \mathrm{m}^{-2} \mathrm{~s}^{-1}$ ). Photosynthesis and transpiration had different values in days with different VPD $(P<0.001$, test $\mathrm{F}$, figure 4). For these analyses, we chose values obtained from well watered plants during March-2 (low VPD) and March-13 (high VPD). Generally, at similar values of gs, photosynthesis was lower and transpiration higher in days with high VPD. In agreement with these observations, $\mathrm{A} / \mathrm{E}$ was higher in the day with lower VPD (figures 4). However, at very low gs (i.e. when the plant is subjected to intensive drought conditions, $\left.0.03 \mathrm{~mol} \mathrm{~m}^{-2} \mathrm{~s}^{-1}\right), \mathrm{A} / \mathrm{E}$ is independent from evaporative demand.

Relationship between net photosynthesis and PPFD. Maximum assimilation values were 5.07 $\pm 0.43( \pm \mathrm{SE}) \mu \mathrm{mol}$ $\mathrm{CO}_{2} \mathrm{~m}^{-2} \mathrm{~s}^{-1}$ and $\mathrm{CP}$ was $10.46 \pm 15.19 \mu \mathrm{mol}$ photon $\mathrm{m}^{-2}$ $\mathrm{s}^{-1}$. Quantum yield was $0.023 \pm 0.007 \mathrm{~mol} \mathrm{C} \mathrm{mol} \mathrm{photon}^{-1}$. Specific leaf area was $9.6 \pm 0.3 \mathrm{~m}^{2} \mathrm{~kg}^{-1}(\mathrm{n}=20)$.

\section{DISCUSSION}

All plants closed their stomata when VPD increased above $2.5 \mathrm{kPa}$, even under non limiting soil water avail-
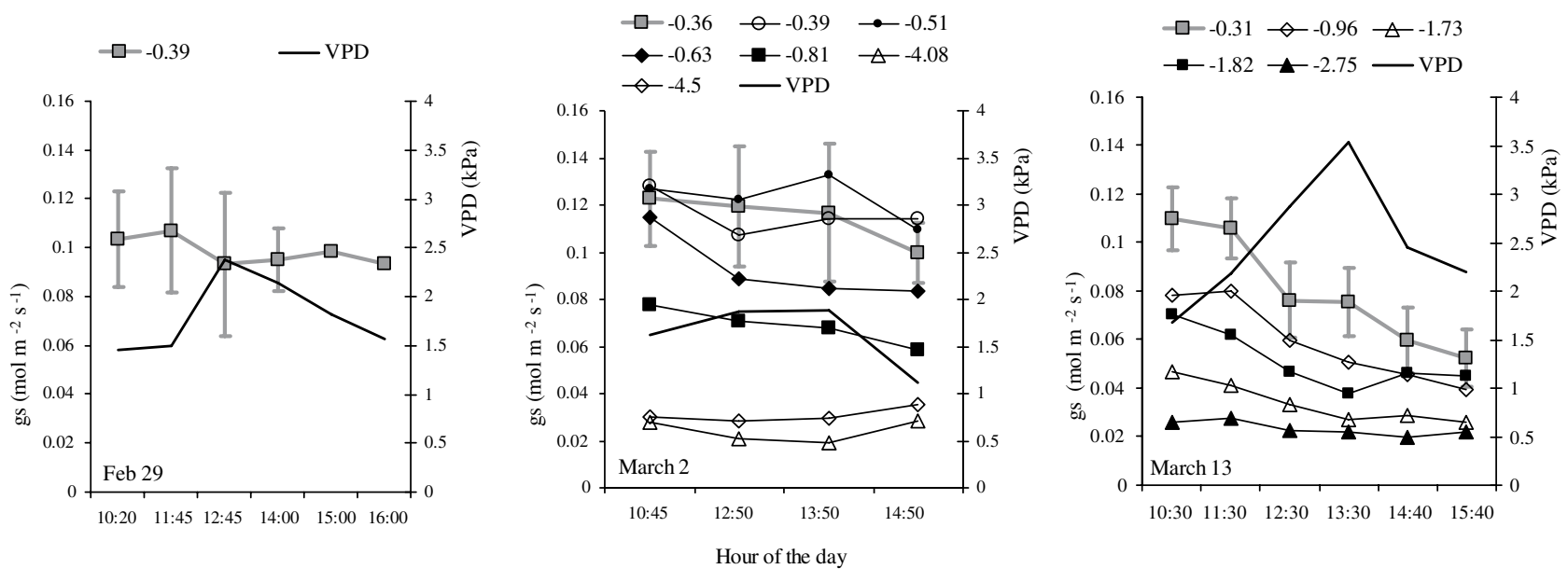

Figure 3. Stomatal conductance ( $\mathrm{gs}, \mathrm{mol} \mathrm{m} \mathrm{m}^{-2} \mathrm{~s}^{-1}$ ) and vapor pressure deficit (VPD, $\mathrm{kPa}$ ) measured at PPFD> $500 \mu \mathrm{mol} \mathrm{m} \mathrm{m}^{-2} \mathrm{~s}^{-1}$ during three days in well watered and Austrocedrus chilensis (grey boxes) and stressed plants (empty and black symbols). The number of series indicates predawn water potential, measured in -MPa. In stressed plants, each point represents one measurement of each seedling, whereas in well watered plants each point is an average of several seedlings.

Conductancia estomática ( $\mathrm{gs}, \mathrm{mol} \mathrm{m} \mathrm{m}^{-2} \mathrm{~s}^{-1}$ ) y déficit de presión de vapor (VPD, $\mathrm{kPa}$ ) medido con PPFD> $500 \mu \mathrm{mol} \mathrm{m}^{-2} \mathrm{~s}^{-1}$ durante tres días en plantines sin (símbolos grises) y con distintos grados de estrés hídrico (símbolos vacíos y negros). El nombre de la serie indica el potencial de prealba en -MPa. En las plantas con estrés hídrico, cada punto se corresponde con un individuo, mientras que en las plantas sin estrés hídrico, cada punto representa el promedio de varios plantines. 

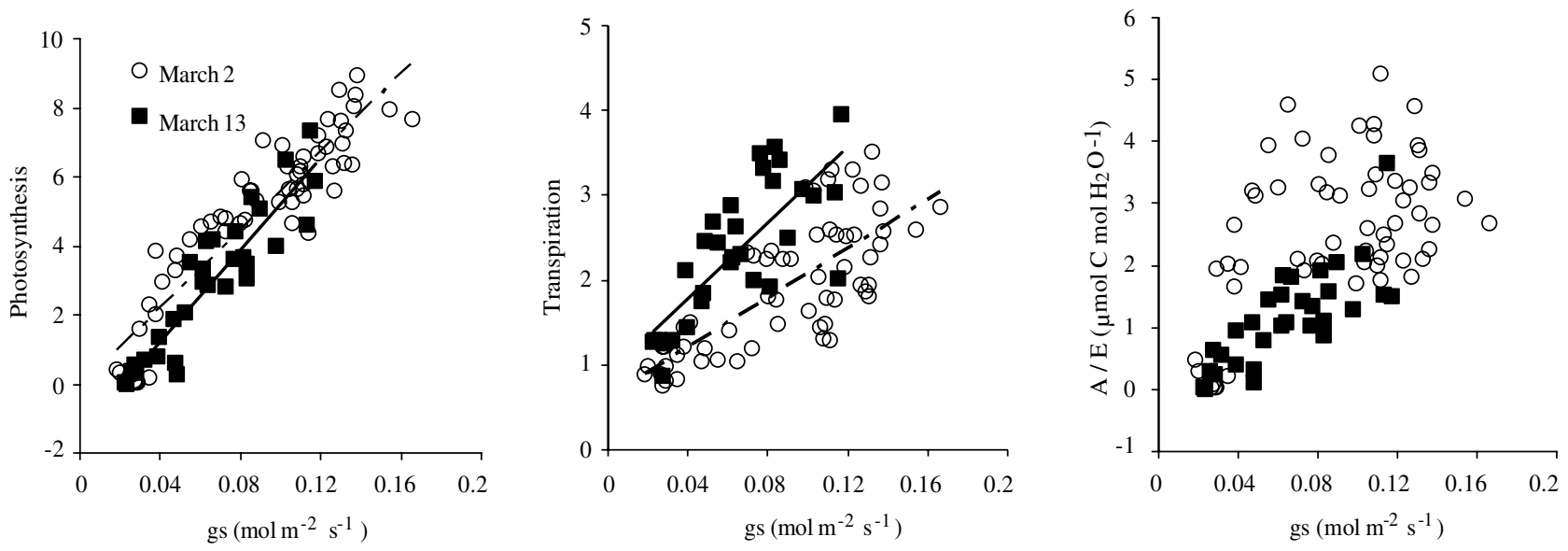

Figure 4. Net photosynthetic rate $\left(\mathrm{A}, \mu \mathrm{mol} \mathrm{CO} \mathrm{m}^{-2} \mathrm{~s}^{-1}\right)$, Transpiration rate $\left(\mathrm{E}, \mathrm{mol} \mathrm{H}_{2} \mathrm{O} \mathrm{m} \mathrm{m}^{-2} \mathrm{~s}^{-1}\right)$ and Instantaneous water use efficiency (A/E) related with gs $\left(\mathrm{mol} \mathrm{m}^{-2} \mathrm{~s}^{-1}\right)$ of Austrocedrus chilensis seedlings in March-2 (1.9 $\mathrm{kPa}$ of maximum VPD) and March-13 (3.5 kPa of maximum VPD) at similar values of solar radiation (PPFD> $500 \mu \mathrm{mol} \mathrm{m}^{-2} \mathrm{~s}^{-1}$ ). Each point represents one measurement.

Tasa neta de fotosíntesis (A, $\mu \mathrm{mol} \mathrm{CO} \mathrm{CO}^{-2} \mathrm{~s}^{-1}$ ), tasa de transpiración (E, mol $\mathrm{H}_{2} \mathrm{O} \mathrm{m}^{-2} \mathrm{~s}^{-1}$ ) y eficiencia instantánea en el uso del agua (A/E) en relación a gs $\left(\mathrm{mol} \mathrm{m}^{-2} \mathrm{~s}^{-1}\right)$ de plantines de Austrocedrus chilensis medidos en dos días con distinto DPV (máximo DPV de 1,9 kPa el 2 marzo y $3,5 \mathrm{kPa}$ el 13 de marzo) con días de similares valores de radiación solar (PPFD> $500 \mu \mathrm{mol} \mathrm{m}^{-2} \mathrm{~s}^{-1}$ ). Cada punto representa una medición.

ability. This threshold VPD value is not a high value for late spring or summer in Patagonia ${ }^{1}$. In addition, stomata sharply closed when $\Psi_{\text {pd }}$ decreased from -0.3 to $-0.8 \mathrm{MPa}$, i.e. under relatively high pre-dawn water potential values. Schlichter (2004) reported that seedlings of A. chilensis growing in the open grassland had $\Psi_{\text {pd }}$ lower than -1 $\mathrm{MPa} 30$ days earlier than seedlings growing under pines reached these values. In addition, plants in the open had minimum $\Psi_{\mathrm{pd}}$ values of $-3.5 \mathrm{MPa}$, while seedlings growing under pine shelter only reached minimum values of -2.0 $\mathrm{MPa}$. The relationship between gs and pre-dawn water potential found in this study was similar to that described for Pinus taeda L., a subtropical species, which grows in humid environments and closes its stomata when the usoil is near -0.6 MPa (Wakamiya-Noborio et al. 1999). However, the low but positive rates of photosynthesis at low stomatal conductances are similar to data reported for several Cedrus and Quercus species (Epron 1997, Fotelli et al. 2000), two Mediterranean species able to survive during periodic droughts. Hydraulic resistance measured in whole plants and their compounds showed that the main resistance to water flow in $A$. chilensis is located at the leaf level (Gyenge et al. 2005). Based on these results, it appears that the strategy of $A$. chilensis seedlings is to sustain favorable water conditions during a drought, by maintaining relatively high water potential by means of an early stomata closure (desiccation avoidance response). This same strategy was found in $Q$. ilex L., which closes its stomata early during the season compared to other Quercus species that overcome drought by means of desiccation tolerance (Fotelli et al. 2000). However, in spite

1 Bustos C. INTA EEA Bariloche, unpublished data. that the effect of temperature on photosynthesis was not measured in our study, several published studies point out that this conservative strategy may be detrimental when transpiration has to act as a heat transfer mechanism (for more information about this mechanism, see Kolb and Robberecht 1996). Other authors have also shown the negative effects of high temperatures applied on the base of the stem or the leaves on plant transpiration and photosynthesis (Huddle and Pallardy 1996, Hamerlynck et al. 2000). This could be taken as one of the causes for the high mortality of $A$. chilensis seedlings under full light conditions even when soil water content was high or similar to that present under shade conditions (Kitzberger et al. 2000, Letournaeu et al. 2004).

Compared with other species, A. chilensis shares some physiological characteristics with shade tolerant species. Stomata of $A$. chilensis were fully open at values of PPFD around $50 \mu \mathrm{mol} \mathrm{m} \mathrm{m}^{-2} \mathrm{~s}^{-1}$, whereas in "heliophilous" species, maximum stomata aperture is reached at values of PPFD of 280-400 $\mu \mathrm{mol} \mathrm{m} \mathrm{m}^{-2} \mathrm{~s}^{-1}$ (Leverenz 1995, Le Roux et al. 1999). In addition, light compensation point was comparatively low (10 compared to 16,23 and $19 \mu \mathrm{mol}$ $\mathrm{m}^{-2} \mathrm{~s}^{-1}$ for P. ponderosa, Pseudotsuga menziesii (Mirb.) Franco, and Tsuga heterophylla (Raf.) Sarg., respectively; Bond et al. 1999). Also, Amax was comparable to that of T. heterophylla, a shade tolerant species (Bond et al. 1999). However, low QY values of A. chilensis $(0.023 \mathrm{~mol} \mathrm{C}$ mol photon ${ }^{-1}$ against $0.052,0.046$ and $0.039 \mathrm{~mol} \mathrm{C}$ mol photon $^{-1}$ for $P$. ponderosa, P. menziesii and T. heterophylla, respectively; Bond et al. 1999) may be detrimental in shaded microenvironments. Based on those results and $\mathrm{A} / \mathrm{E}$ measurements, microenvironments with intermediate shade may be the best for $A$. chilensis seedling growth. 
In summary, the results may indicate that drought avoidance behavior through early stomatal closure could be the main mechanism used by this species to survive under soil water deficits coupled with high evaporative demand. However, studies in other species with the same strategy indicate that the risk of photoinhibition or cell damage due to over-heating is increased under this situation. For this reason, shelter imposed by shrubs (natural conditions) or other trees (artificial plantations) may be a possible way to avoid these processes derived from excessive radiation. Further research is needed in order to evaluate this hypothesis. In addition, photosynthetic performance was comparable to that of shade tolerant species regarding some parameters (light compensation point, stomatal conductance at low PPFD levels). However, at the same time, quantum yield indicated a low $\mathrm{C}$ fixation capacity at low light levels. As a whole, the results further our understanding on the need of nurse plants for successful recruitment of $A$. chilensis, and at the same time, they help explaining its very low growth rates under highly shaded conditions (Kitzberger et al. 2000).

\section{ACKNOWLEDGMENTS}

This research was partially funded by INTA (National Institute for Agricultural Technology) and SAGPyA through the project PIA 16/98. ME Fernández was supported by a fellowship for graduate students of CONICET. We also thank the support of the Genetics Group of INTA EEA Bariloche, which provided the plants for the experiments. We gratefully acknowledge Guillermina Dalla Salda for her valuable comments on this manuscript.

\section{REFERENCES}

Bond BJ, BT Farnsworth, RA Coulombe, WE Winner. 1999. Foliage physiology and biochemistry in response to light gradients in conifers with varying shade tolerance. Oecologia 120:183-192.

Dezzotti A, L Sancholuz. 1991. Los bosques de Austrocedrus chilensis en Argentina: ubicación, estructura y crecimiento. Bosque 12(2):43-52.

Epron D. 1997. Effects of drought on photosynthesis and on the thermotolerance of photosystem II in seedlings of cedar (Cedrus atlantica and C. libani). J. Exp. Bot. 48:1835-1841.

Ewers BE, R Oren. 2000. Analysis of assumptions and errors in the calculation of stomatal conductance from sap flux measurements. Tree Physiol. 20:579-589.

Fotelli MN, KM Radoglou, HIA Constantinidou. 2000. Water stress responses of seedlings of four Mediterranean oak species. Tree Physiol. 20:1065-1075.

Fernández ME, JE Gyenge, TM Schlichter. 2006. Growth of Festuca pallescens in silvopastoral systems in Patagonia, Part 2: Parametrization of models od stomatal conductance and leaf photosynthesis. Agrof. Syst. 66:271-280.
Gyenge JE, ME Fernández, G Dalla Salda, T Schlichter. 2005. Leaf and whole-plant water relations of the Patagonian conifer Austrocedrus chilensis (D.Don) Pic. Ser. et Bizzari: implications on its drought resistance capacity. Ann. For. Sci. 62:297-302.

Gobbi M, T Schlichter. 1998. Survival of Austrocedrus chilensis seedlings in relation to microsite conditions and forest thinning. For. Ecol. Manage. 111:137-146.

Huddle JA, SG Pallardy. 1996. Effects of soil and stem base heating on survival, resprouting and gas exchange of Acer and Quercus seedlings. Tree Physiol. 16: 583-589.

Hamerlynck EP, TE Huxman, ME Loik, SD Smith. 2000. Effects of extreme high temperature, drought and elevated $\mathrm{CO}_{2}$ on photosynthesis of the Mojave Desert evergreen shrub, Larrea tridentate. Plant Ecology 148: 183-193.

Kitzberger T, DF Steinaker, TT Veblen. 2000. Effects of climatic variability on facilitation of tree establishment in Northern Patagonia. Ecology 81:1914-1924.

Kitzberger T. 1995. Fire regime variation along a northern Patagonian forest-steppe gradient: stand and landscape responses. PhD Dissertation. Colorado, USA. Department of Geography, Univ. of Colorado. 203 p.

Kolb PF, R Robberecht. 1996. High temperature and drought stress effects on survival of Pinus ponderosa seedlings. Tree Physiol. 16:665-672.

Landsberg J. 1977. Some useful equations for biological studies. Exp. Agric. 13:273-286.

Le Roux X, S Grand, E Dreyer, F-A Daudet. 1999. Parametrization and testing of a biochemically based photosynthesis model for walnut (Juglans regia) trees and seedlings. Tree Physiol. 19:481-492.

Letourneau FJ, E Andenmatten, T Schlichter. 2004. Effect of climatic conditions and tree size on Austrocedrus chilensis-shrub interactions in northern Patagonia. For. Ecol. Manage. 191:29-38.

Leverenz JW. 1995. Shade shoot structure of conifers and the photosynthetic response to light at two $\mathrm{CO}_{2}$ partial pressures. Func. Ecol. 9:413-421.

Maherali H, EH DeLucia, TW Sipe. 1997. Hydraulic adjustment of maple saplings to canopy gap formation. Oecologia 112:472-480.

Neter J, W Wasserman. 1974. Applied linear statistical models. Regression, analysis of variance and experimental design. Homewood, Illinois, USA. RD Irwin Inc. 842 p.

Pastorino M. 2000. Genetic variation and reproduction system of Austrocedrus chilensis (D.Don) Florin et Boutelje, a cypress endemic to the Andean-Patagonian Forest. PhD Thesis. Göttingen, Germany. Göttingen Univ. Cuvillier Verlag. 166 p.

Schlichter T. 2004. PIA 16/98: Plantaciones de "ciprés de la cordillera" bajo cubierta de "pino ponderosa". In Investigación Forestal al servicio de la producción II. Resultados aplicables al cultivo de bosques y la producción de madera en la Argentina. Proyecto Forestal de Desarrollo, Secretaría de Agricultura, Ganadería, Pesca y Alimentos, Buenos Aires, Argentina. p. 33-43.

Wakamiya-Noborio I, JL Heilman, RJ Newton, MG Messina. 1999. Diurnal changes in water conduction in loblolly pine (Pinus taeda) and Virginia pine (P. virginiana) during soil dehydration. Tree Physiol. 19:575-581. 